\title{
Inter-population differences in temperature effects on Engraulis ringens yolk-sac larvae
}

\author{
Alejandra Llanos-Rivera ${ }^{1,2, *}$, Leonardo R. Castro ${ }^{2}$ \\ ${ }^{1}$ Programa Doctorado en Ciencias Mención Zoología, Departamento de Zoología, and ${ }^{2}$ Laboratorio de Oceanografía \\ Pesquera y Ecología Larval (LOPEL), Departamento de Oceanografía, Universidad de Concepción, Casilla 160-C, \\ Concepción, Chile
}

\begin{abstract}
Early life stages of Engraulis ringens were reared from hatch until yolk exhaustion. We evaluated the effect of temperature on characteristics such as larval length and yolk volume at hatch, larval length at yolk absorption, duration of yolk-sac stage, yolk consumption rate and larval growth rate. Further, we determined the potential differences in these traits between populations located $13^{\circ}$ of latitude apart (Antofagasta $23^{\circ} \mathrm{S}$, Talcahuano $36^{\circ} \mathrm{S}$ ). The results showed that egg size had an effect on the larval length at hatch, initial yolk volume and larval length at yolk absorption, since the values obtained were always larger in larvae hatched from Talcahuano (from larger eggs) than from Antofagasta (smaller eggs). These characteristics were also modified by the rearing temperature. Duration of yolk-sac phase, yolk consumption rate and larval growth rate until yolk exhaustion showed high thermic dependence in both populations. However, these traits showed no difference between populations when larvae were reared at the same temperature in the range between 12 and $20^{\circ} \mathrm{C}$, despite their initial difference in egg size. When extrapolated from the environmental conditions in each nursery area (i.e. $15^{\circ} \mathrm{C}$ Antofagasta and $12^{\circ} \mathrm{C}$ Talcahuano), our results suggest that the anchoveta populations from Talcahuano compensate for their lower larval growth rates by increasing their initial egg and hatch sizes, as they are larger than Antofagasta larvae at the end of the yolk-sac stage. This increased larval length should enhance their chances of survival under adverse environmental conditions, such as high turbulence, lower temperature and lower food availability during winter, which is typical of the anchoveta southern spawning area.
\end{abstract}

KEY WORDS: Anchoveta · Early life-history traits $\cdot$ Egg size $\cdot$ Growth $\cdot$ Latitudinal differences · Temperature effects

\section{INTRODUCTION}

A number of environmental parameters that may directly affect the chances of early larval survival vary with latitude. Among them, temperature and day length, especially during winter, have been widely studied (Houde 1989, Conover 1990). The early life stages of species that are distributed across a wide latitudinal range, therefore, are likely to have either behavioral or physiological mechanisms to cope with variations in environmental characteristics.

The anchoveta Engraulis ringens is a coastal pelagic species found from northern Peru $\left(4^{\circ} 30^{\prime} \mathrm{S}\right)$ to southern Chile $\left(42^{\circ} 30^{\prime} \mathrm{S}\right.$; Serra et al. 1979). Three major spawn- ing areas have been identified: north (northern Peru), central (southern Peru to northern Chile) and south (central Chile). Environmental characteristics, such as temperature, turbulence index and upwelling index, vary widely within this range (Castro et al. 2001). Egg size of the anchoveta during the peak spawning season also varies with latitude (e.g. $0.20 \mathrm{~mm}^{3}$ at $20^{\circ} \mathrm{S}$ and $0.31 \mathrm{~mm}^{3}$ at $36^{\circ} \mathrm{S}$; Llanos-Rivera \& Castro 2004). Whether these differences are reflected in variations among yolk-sac larval characteristics is unknown and is a main objective of this study.

Temperature has a strong effect on development and physiological rates of larval fishes (Blaxter 1992). A change in temperature can influence larval size at 
hatching and accelerate the development of larval attributes, such as the pigmentation of the eye and the formation of the jaw (Lasker 1964). Generally, larvae incubated at higher temperatures are shorter at the time of hatching. However, in a wider temperature range, length at hatch is maximal at intermediate temperatures and smallest at extremes of low and high temperatures (Chambers 1997). Interestingly, small differences in size at this stage may confer large differences in survival. Larvae that are larger at hatch are more resistant to starvation, and show a greater flexibility in prey selection at the time of first feeding (Miller et al. 1988). Differences in the size at hatch may be an adaptive response to local geographical conditions (Miller et al. 1988).

Temperature also affects early larval growth and yolk consumption rates (Koumoundouros et al. 2001). The effect of temperature, however, may vary among stages, as each developmental stage may have different growth rates. Embryos grow slowly from fertilization to hatching; yolk-sac larvae grow more quickly until they reach the maximum size that their endogenous reserves allow; feeding larvae exhibit relatively slow growth rates at the beginning of exogenous feeding (Kamler 1992).

Abundant information exists on egg development rates for many marine species, especially those of commercial value for stock assessment purposes (Lo 1985). There is an increasing amount of information on larval growth rates, either collected from the field (i.e. based on daily increments on otoliths, Hernández \& Castro 2000, Gaughan et al. 2001) or from rearing experiments (tanks and mesocosms, Brown et al. 1998, Otterlei et al. 1999, Van der Meeren \& Jorstad 2001). Few studies have addressed the effects of temperature on yolk-sac larvae, probably because of their short duration, fragility and the paucity of easily scored morphological characteristics. In this intermediate stage, it is possible to evaluate direct parental effects on the survival of new larvae (i.e. yolk quality and quantity). The assessment of the parental input may be of great value, for instance, for determining whether characters at this stage are susceptible to selection, especially for populations exposed to contrasting environmental conditions (Chambers 1997), such as in species located over a wide latitudinal range.

During the past decade, we have conducted a series of studies on how different populations of anchoveta cope with latitudinal variations in their environment. We previously described latitudinal variations in anchoveta egg size during the peak spawning season along the Chilean coast (Llanos-Rivera \& Castro 2004) and identified several environmental characteristics that might possibly affect the chances of survival of the young life stages (Castro \& Hernández 2000, Castro et al. 2001). Here, we evaluated the effect of temperature on several yolk-sac characteristics of anchoveta hatched from eggs of different sizes collected from 2 areas separated by $13^{\circ}$ latitude. The characteristics evaluated were length at hatch, yolk volume at hatch, length at yolk absorption, duration of the yolk-sac phase, yolk consumption rate and growth prior to yolk absorption. With this type of information, we finally assessed whether potential differences between populations in the larval size at hatch are compensated for prior to yolk absorption by means of variations in larval growth rates during the yolk-sac larval stage.

\section{MATERIALS AND METHODS}

In 2001, a series of oceanographic cruises to the coastal areas of Antofagasta $\left(23^{\circ} 05^{\prime} \mathrm{S}, 70^{\circ} 30^{\prime} \mathrm{W}\right)$ and Talcahuano $\left(36^{\circ} 32^{\prime} \mathrm{S}, 72^{\circ} 56^{\prime} \mathrm{W}\right)$ (Fig. 1) were carried out during the winter peak spawning of the anchoveta Engraulis ringens. During this season (July to September, Cubillos et al. 1999) the sea surface temperatures decrease with increasing latitude. Surface temperature in the northern spawning area $\left(23^{\circ} \mathrm{S}\right.$, Antofagasta) varies from 15 to $20^{\circ} \mathrm{C}$, and in the southern spawning area (Talcahuano, $36^{\circ} \mathrm{S}$ ) it varies from 11 to $15^{\circ} \mathrm{C}$ (Fig. 1).

Gently oblique hauls were carried out at 1.5 knots (conical net, $300 \mu \mathrm{m}$ mesh), and the plankton was deposited in black plastic buckets (30 1) with seawater from the same sampling area. The anchovy eggs were separated from the plankton in $<2 \mathrm{~h}$ from the time of collection, using a stereomicroscope.

Eggs from early development stages (Phases I and II following Fisher 1958) were utilized for rearing experiments. Sets of 50 eggs were placed in 11 flasks with $0.5 \mu \mathrm{m}$ filtered, UV-sterilized seawater. Flasks were placed in 5 temperature-controlled baths set at 10, 12, 15,18 and $20^{\circ} \mathrm{C}$ and held under a $12 \mathrm{~h}$ light:12 h dark photoperiod.

Two trials (4 d apart) were conducted in each area following this protocol. All rearing temperatures were used except in the second series for Talcahuano, where the $20^{\circ} \mathrm{C}$ temperature was not evaluated. Close to the time of hatching, the rearing containers were checked every hour for newly hatched larvae. A total of 28 or 30 recently hatched larvae (max. 30 min from hatch) were anesthetized and measured live. Notochord length and yolk-sac size (length and maximum width) were measured under a stereomicroscope equipped with an ocular micrometer $(20 \times)$. Larval yolk-sac volume was estimated assuming a half-ellipsoid shape $(4 \pi a b c / 6$, where $a, b$ and $c$ correspond to ellipse radii). To avoid underestimating the larval measurements due to shrinkage, the larvae were anesthetized (Bz-20, benzocaine Veterquimica, Chile). Over the course of the experiment, 


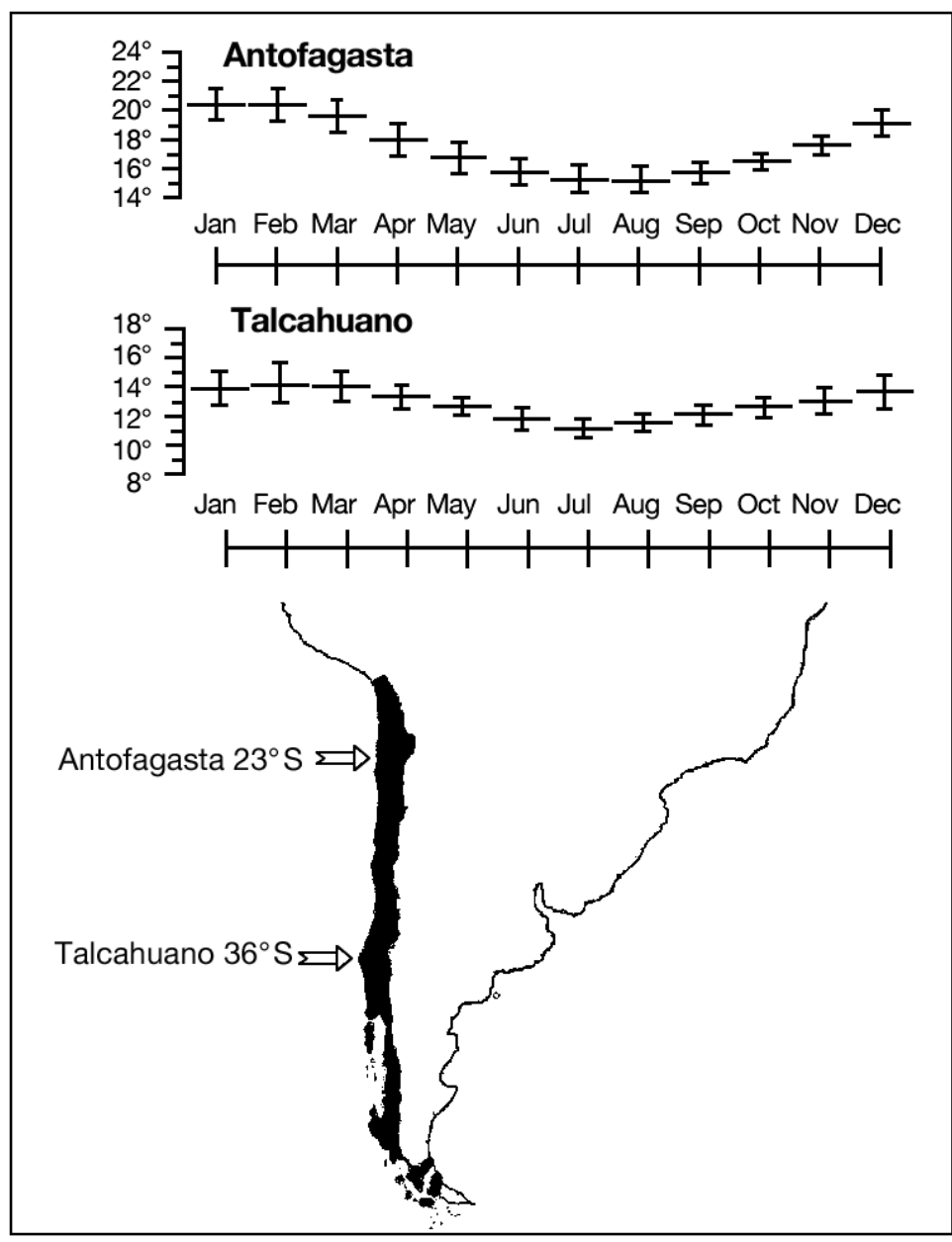

Fig. 1. Time series from 1970 to 1999 of mean $( \pm$ SD) sea surface temperature $\left({ }^{\circ} \mathrm{C}\right)$ measured at tidal gauge stations along the Chilean coast

area and comparing the parameter estimates with a covariance analysis between them (ANCOVA, Zar 1984). Similarly, the rate of yolk consumption was estimated as the slope of linear regression of Ln yolk volume $\left(\mathrm{mm}^{3}\right)$ versus time $(\mathrm{h})$ in each area at each temperature. Then, with covariance analyses, we compared their slopes between temperatures within areas and then between areas.

We fit both a non-linear (Gompertz model: $\left.L=L_{\mathrm{o}} \exp \{G[1-\exp (-g t)]\}\right)$ and simple linear model (linear model: $L=L_{\mathrm{o}}+B t$ ) to the growth data from hatch to yolk absorption, where $L=$ length at age $t_{i} L_{\mathrm{o}}=$ length at hatch; $G=\mathrm{a}$ dimensionless parameter; $g=$ instantaneous growth rate at age $t_{\mathrm{o}} ; t_{\mathrm{o}}=$ an inflection point of the curve and the age at which absolute growth begins to decline; and $B=$ growth rate (STATISTICA 5.0 for Windows, 1996, StatSoft). The best model was selected under the Akaike information criterion (AIC, Quinn \& Deriso 1999). Differences in growth rates between areas and for the different temperatures were determined by estimating the confidence intervals (95\% CI) obtained by means of bootstrap analysis based on 1000 iterations (Manly 1997). Differences in growth rate were considered significant if the confidence intervals were distinct and non-overlapping.

Finally, we checked if differences in egg size between areas occurred as previously reported in studies along the Humboldt Current (Llanos-Rivera \& Castro 2004), by collecting and measuring a sub-sample of eggs

from the larvae remaining in the experimental flasks, about 10 larvae were collected from each temperature treatment at different time intervals and measured live. Because the rate of yolk absorption is accelerated at higher temperatures (Kamler et al. 1994), measurements were repeated at time intervals from $12\left(20^{\circ} \mathrm{C}\right)$ to $28 \mathrm{~h}\left(10^{\circ} \mathrm{C}\right)$, to include the entire process until the event of yolk exhaustion and eye pigmentation.

The effects of rearing temperatures and area on length at hatch, initial yolk volume, length at yolk absorption and time of yolk absorption were tested in a nested ANOVA (analysis of variance), in which trials were nested in areas. Differences in these variables among temperatures were tested with a Tukey a posteriori multiple comparison (Zar 1984). To evaluate the effect of temperature within each area, we utilized an ANOVA with trials and temperatures as factors and the same Tukey a posteriori multiple comparison.

The temperature effect on yolk-sac stage duration for each egg source (area) was evaluated by applying a linear model of Ln time $(\mathrm{h})$ over temperature $\left({ }^{\circ} \mathrm{C}\right)$ for each (preserved in $5 \%$ formalin) from all experimental trials. Egg volume was estimated from $4 \pi a b c / 3$, where $a, b$ and $c$ correspond to ellipse radii. We utilized a nested ANOVA, in which trials were nested in egg origin.

\section{RESULTS}

\section{Length at hatch, yolk-sac volume and length at yolk absorption}

The results of an ANOVA that considered temperature, area and trials as sources of variance revealed that temperature had an effect on the length at hatch, yolksac volume and length at yolk absorption in larvae from both areas (Table 1). These larval characteristics reached smaller values at the highest temperatures (Tukey test: length at hatch, df $=495$, p < 0.001; yolksac volume, $\mathrm{df}=495, \mathrm{p}<0.05$; length at yolk absorption, $\mathrm{df}=300, \mathrm{p}<0.001$, Fig. 2). However, a second ANOVA carried out by area assessed the effect of temperature 


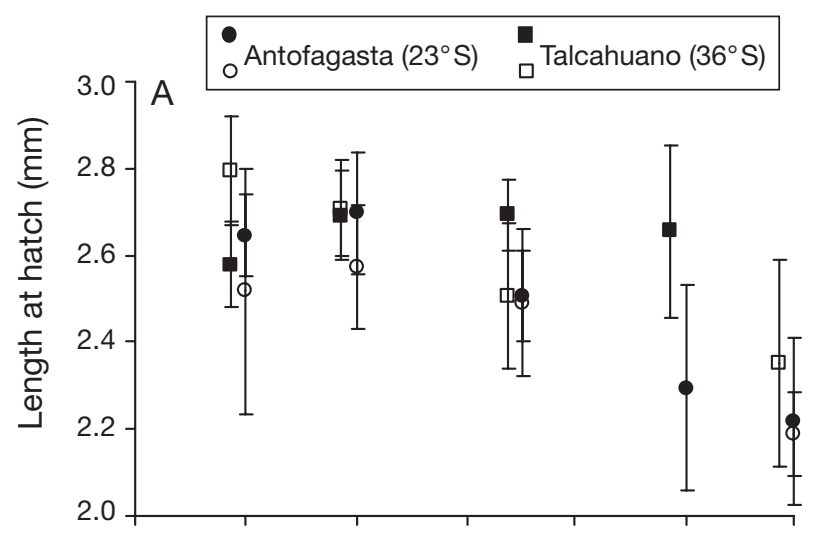

Table 1. Engraulis ringens. Results of ANOVA to test for effects of temperature, area and trial on early larval traits. Values in bold: significant values

\begin{tabular}{|lrrc|}
\hline Source of variation & df & $F$ & $\mathrm{p}$ \\
\hline Length at hatch $\mathbf{( m m )}$ & & & \\
Temperature & 4 & 78.68 & $\mathbf{0 . 0 0 0 0 0 0}$ \\
Area & 1 & 30.66 & $\mathbf{0 . 0 3 4 1 3 9}$ \\
Trial (area) & 2 & 2.29 & 0.101972 \\
Error & 495 & & \\
Yolk volume at hatch $\mathbf{( m m}^{3}$ ) & & & \\
Temperature & 4 & 3.59 & $\mathbf{0 . 0 0 6 7 0 9}$ \\
Area & 1 & 115.53 & $\mathbf{0 . 0 0 9 3 0 0}$ \\
Trial (area) & 2 & 3.91 & $\mathbf{0 . 0 2 0 5 8 2}$ \\
Error & 495 & & \\
Length at yolk absorption $\mathbf{( m m )}$ & & & \\
Temperature & 4 & 5.41 & $\mathbf{0 . 0 0 0 3 2 0}$ \\
Area & 1 & 100.99 & $\mathbf{0 . 0 0 8 6 3 0}$ \\
Trial (area) & 2 & 3.94 & $\mathbf{0 . 0 2 0 3 9 3}$ \\
Error & 300 & & \\
\hline
\end{tabular}

$\mathrm{p}<0.05$ ) (Table 2, Fig. 2A). In Talcahuano, differences in the length at hatch were determined only among temperatures (ANOVA: temperature $F_{(4,229)}=28.68, \mathrm{p}=$ 0.0001 ), with the smallest larvae being those hatched at the highest temperatures (Tukey test: $\mathrm{df}=229, \mathrm{p}<0.05$ ).

Only in Talcahuano did differences exist in yolk-sac volume of recently hatched larvae among temperatures (ANOVA: $F_{(4,229)}=3.95, \mathrm{p}=0.0040$ ) and trials (ANOVA: $F_{(1,229)}=7.426, \mathrm{p}=0.0069$ ). The differences in yolk-sac volume (highest and lowest volumes) occurred at temperatures between 15 and $20^{\circ} \mathrm{C}$ (Tukey test: $\mathrm{df}=227, \mathrm{p}<0.05)$ (Fig. 2B, Table 2). Between trials, the differences were due to the lowest value of yolk-sac volume, which was observed at $20^{\circ} \mathrm{C}$ (Tukey test: $15^{\circ} \mathrm{C}$ (Trial 2) vs. 20 and $12^{\circ} \mathrm{C}$ (Trial 2) vs. $20^{\circ} \mathrm{C}$, $\mathrm{df}=227, \mathrm{p}<0.05)$.

Finally, while no differences in length at yolk absorption occurred between trials in Talcahuano, temperature did have an effect (ANOVA: $F_{(4,179)}=7.46, \mathrm{p}=0.00014$ ). Larvae maintained at 12,18 and $20^{\circ} \mathrm{C}$ absorbed their yolk at a smaller size than those reared at $10^{\circ} \mathrm{C}$ (Tukey test: $\mathrm{df}=179, \mathrm{p}<0.05)$ (Fig. 2C, Table 2). In Antofagasta, in turn, no differences were observed in the length at yolk absorption either among temperatures or trials (ANOVA: temperature, $F_{(4,117)}=2.29, \mathrm{p}=0.063$; trials, $\left.F_{(1,117)}=3.05, \mathrm{p}=0.083\right)$. In both areas yolk absorption occurred coincidently with eye pigmentation.

\section{Yolk-sac period duration, yolk consumption and larval growth}

Temperature had an inverse effect on yolk-sac stage duration. The inverse power model between temperature and yolk stage duration (YSD) (Fig. 3A) predicts a 2 -fold increase of yolk duration with a decrease of $5^{\circ} \mathrm{C}$ 
Table 2. Engraulis ringens. Early traits of larvae reared at different temperatures in Antofagasta and Talcahuano. Values correspond to the mean $( \pm \mathrm{SD}$, in parentheses) of 2 experimental trials carried out in each area

\begin{tabular}{|c|c|c|c|c|c|c|c|c|c|c|}
\hline & \multicolumn{5}{|c|}{ Antofagasta $\left(23^{\circ} \mathrm{S}\right)$} & \multicolumn{5}{|c|}{ Talcahuano $\left(36^{\circ} \mathrm{S}\right)$} \\
\hline & $10^{\circ} \mathrm{C}$ & $12^{\circ} \mathrm{C}$ & $15^{\circ} \mathrm{C}$ & $18^{\circ} \mathrm{C}$ & $20^{\circ} \mathrm{C}$ & $10^{\circ} \mathrm{C}$ & $12^{\circ} \mathrm{C}$ & $15^{\circ} \mathrm{C}$ & $18^{\circ} \mathrm{C}$ & $20^{\circ} \mathrm{C}$ \\
\hline Length at hatch (mm) & $\begin{array}{c}2.58 \\
(0.22)\end{array}$ & $\begin{array}{c}2.64 \\
(0.15)\end{array}$ & $\begin{array}{c}2.50 \\
(0.14)\end{array}$ & $\begin{array}{c}2.29 \\
(0.24)\end{array}$ & $\begin{array}{c}2.20 \\
(0.15)\end{array}$ & $\begin{array}{c}2.69 \\
(0.16)\end{array}$ & $\begin{array}{c}2.70 \\
(0.11)\end{array}$ & $\begin{array}{c}2.60 \\
(0.08)\end{array}$ & $\begin{array}{c}2.66 \\
(0.20)\end{array}$ & $\begin{array}{c}2.35 \\
(0.24)\end{array}$ \\
\hline Yolk sac volume at hatch $\left(\mathrm{mm}^{3}\right)$ & $\begin{array}{c}0.097 \\
(0.013)\end{array}$ & $\begin{array}{c}0.099 \\
(0.014)\end{array}$ & $\begin{array}{c}0.098 \\
(0.012)\end{array}$ & $\begin{array}{c}0.096 \\
(0.015)\end{array}$ & $\begin{array}{c}0.094 \\
(0.015)\end{array}$ & $\begin{array}{c}0.126 \\
(0.016)\end{array}$ & $\begin{array}{c}0.130 \\
(0.017)\end{array}$ & $\begin{array}{c}0.132 \\
(0.018)\end{array}$ & $\begin{array}{c}0.121 \\
(0.016)\end{array}$ & $\begin{array}{c}0.120 \\
(0.015)\end{array}$ \\
\hline Length at yolk-absorption (mm) & $\begin{array}{c}3.97 \\
(0.15)\end{array}$ & $\begin{array}{c}4.04 \\
(0.27)\end{array}$ & $\begin{array}{c}4.16 \\
(0.14)\end{array}$ & $\begin{array}{c}4.14 \\
(0.14)\end{array}$ & $\begin{array}{c}4.14 \\
(0.16)\end{array}$ & $\begin{array}{c}4.60 \\
(0.17)\end{array}$ & $\begin{array}{c}4.42 \\
(0.16)\end{array}$ & $\begin{array}{c}4.54 \\
(0.15)\end{array}$ & $\begin{array}{c}4.52 \\
(0.15)\end{array}$ & $\begin{array}{c}4.40 \\
(0.16)\end{array}$ \\
\hline
\end{tabular}

$\left(\mathrm{YSD}_{\text {Antofagasta }}=6316 \times T^{-1.55} ; \mathrm{YSD}_{\text {Talcahuano }}=13069 \times\right.$ $\left.T^{-1.86}\right)$. In both populations, the strongest difference in YSD among temperatures was observed at the lowest temperature range $\left(10\right.$ to $\left.12^{\circ} \mathrm{C}\right)$. For instance, a decrease in $2^{\circ} \mathrm{C}$ in this range increased the YSD by $2 \mathrm{~d}$, while a decrease between 20 and $18^{\circ} \mathrm{C}$ increased the yolk duration by $0.4 \mathrm{~d}$. Accordingly, yolk consumption rate $\left(\mathrm{mm}^{3} \mathrm{~h}^{-1}\right)$ increased significantly with temperature in both populations (Table 3; ANCOVA: Antofagasta, $\mathrm{n}=$ 982, $\mathrm{p}<0.001$; Talcahuano, $\mathrm{n}=968, \mathrm{p}<$ 0.001) (Fig. 3B). When comparing between areas, no differences in yolk-sac phase duration (Table 3; ANCOVA: $n=17, \mathrm{p}>0.05$ ) or yolk exhaustion rate were observed (ANCOVA: $\mathrm{n}=1950, \mathrm{p}>0.05$ ).

Growth in length of yolk-sac larvae was best described by a non-linear Gompertz model at all temperatures (Table 4). Growth rates of yolk-sac larvae increased with temperature for larvae from both areas (Fig. 3C). A trend was observed in which at the highest temperatures $\left(18\right.$ to $20^{\circ} \mathrm{C}$ ) northern larvae grew faster than southern larvae. Alternatively, at the lowest temperatures $\left(10\right.$ to $12^{\circ} \mathrm{C}$ ) larvae from the southern population grew faster than larvae from the northern location. However, differences in the growth rate of larvae between areas were only statistically significant at the lowest temperature $\left(10^{\circ} \mathrm{C}\right)$.

In larvae from Antofagasta, changes in a few degrees of temperature resulted in different variations in growth rates between the lowest and highest temperature ranges (Fig. 3C, Table 3). For instance, while a change in $2^{\circ} \mathrm{C}$ (between 10 and $12^{\circ} \mathrm{C}$ ) resulted in a $0.10 \mathrm{~mm} \mathrm{~d}^{-1}$ increase in growth rate $(58.8 \%)$, in the highest temperature range $\left(18\right.$ to $\left.20^{\circ} \mathrm{C}\right)$ the $2^{\circ} \mathrm{C}$ change resulted in a growth rate increase of $0.27 \mathrm{~mm} \mathrm{~d}^{-1}$ $(45.8 \%)$. The growth rate of yolk-sac larvae from Talcahuano did not change in the lower temperature range (between 10 and $12^{\circ} \mathrm{C}$ ), but did change in the highest temperature range (from 18 to $20^{\circ} \mathrm{C}$ ), increasing by $35.2 \%$.

\section{Interpopulation differences in larval sizes and egg volumes}

Egg size (volume) differed between source areas (ANOVA: $\left.F_{(2,819)}=5532, \mathrm{p}=0.0001\right)$ and also between trials (ANOVA: $F_{(2,819)}=8.576, \mathrm{p}=0.0002$ ), but the difference between trials was much smaller than between areas (Table 2). Eggs from the southern population were, on average, larger than those from the north $\left(23^{\circ} \mathrm{S}\right)$ (Table 5, Fig. 4). Thus, egg size, length at hatch, initial yolk volume and length at yolk absorption are characteristics of the early life stages that differ between populations, being larger in individuals originating from the southern population (Talcahuano) (Fig. 4).

Table 3. Engraulis ringens. Early rates of larvae reared at different temperatures in Antofagasta and Talcahuano. Values correspond to the mean $( \pm \mathrm{SD}$, in parentheses) of 2 experimental trials carried out in each area

\begin{tabular}{|c|c|c|c|c|c|c|c|c|c|}
\hline & \multicolumn{5}{|c|}{ Antofagasta $\left(23^{\circ} \mathrm{S}\right)$} & \multicolumn{4}{|c|}{ Talcahuano $\left(36^{\circ} \mathrm{S}\right)$} \\
\hline & $10^{\circ} \mathrm{C}$ & $12^{\circ} \mathrm{C}$ & $15^{\circ} \mathrm{C}$ & $18^{\circ} \mathrm{C}$ & $20^{\circ} \mathrm{C}$ & $10^{\circ} \mathrm{C}$ & $12^{\circ} \mathrm{C} \quad 15^{\circ} \mathrm{C}$ & $18^{\circ} \mathrm{C}$ & $20^{\circ} \mathrm{C}$ \\
\hline Growth rate $\left(\mathrm{mm} \mathrm{d}^{-1}\right)$ & $\begin{array}{c}0.17 \\
(0.019)\end{array}$ & $\begin{array}{c}0.27 \\
(0.022)\end{array}$ & $\begin{array}{c}0.48 \\
(0.022)\end{array}$ & $\begin{array}{c}0.59 \\
(0.121)\end{array}$ & $\begin{array}{c}0.86 \\
(0.047)\end{array}$ & $\begin{array}{c}0.22 \\
(0.004)\end{array}$ & $\begin{array}{cc}0.33 & 0.47 \\
(0.042) & (0.031)\end{array}$ & $\begin{array}{l}0.54 \\
(0.06)\end{array}$ & 0.73 \\
\hline Yolk consumption rate $\left(\mathrm{Ln} \mathrm{mm}^{3} \mathrm{~h}^{-1}\right)$ & $\begin{array}{c}0.026 \\
(0.009)\end{array}$ & $\begin{array}{c}0.041 \\
(0.013)\end{array}$ & $\begin{array}{c}0.057 \\
(0.018)\end{array}$ & $\begin{array}{c}0.093 \\
(0.039)\end{array}$ & $\begin{array}{l}0.086 \\
(0.022)\end{array}$ & $\begin{array}{c}0.018 \\
(0.002)\end{array}$ & $\begin{array}{cc}0.042 & 0.044 \\
(0.016) & (0.00007)\end{array}$ & $\begin{array}{r}0.0892 \\
(0.003)\end{array}$ & $\begin{array}{c}0.103 \\
0\end{array}$ \\
\hline Duration yolk-sac phase (d) & 8.08 & 5.38 & $\begin{array}{c}3.29 \\
(0.177)\end{array}$ & $\begin{array}{c}2.62 \\
(0.059)\end{array}$ & $\begin{array}{c}2.14 \\
(0.088)\end{array}$ & $\begin{array}{c}7.96 \\
(0.059)\end{array}$ & $\begin{array}{cc}5.22 & 3.88 \\
(0.309) & (0.177)\end{array}$ & $\begin{array}{c}3.02 \\
(0.147)\end{array}$ & 2.7 \\
\hline
\end{tabular}



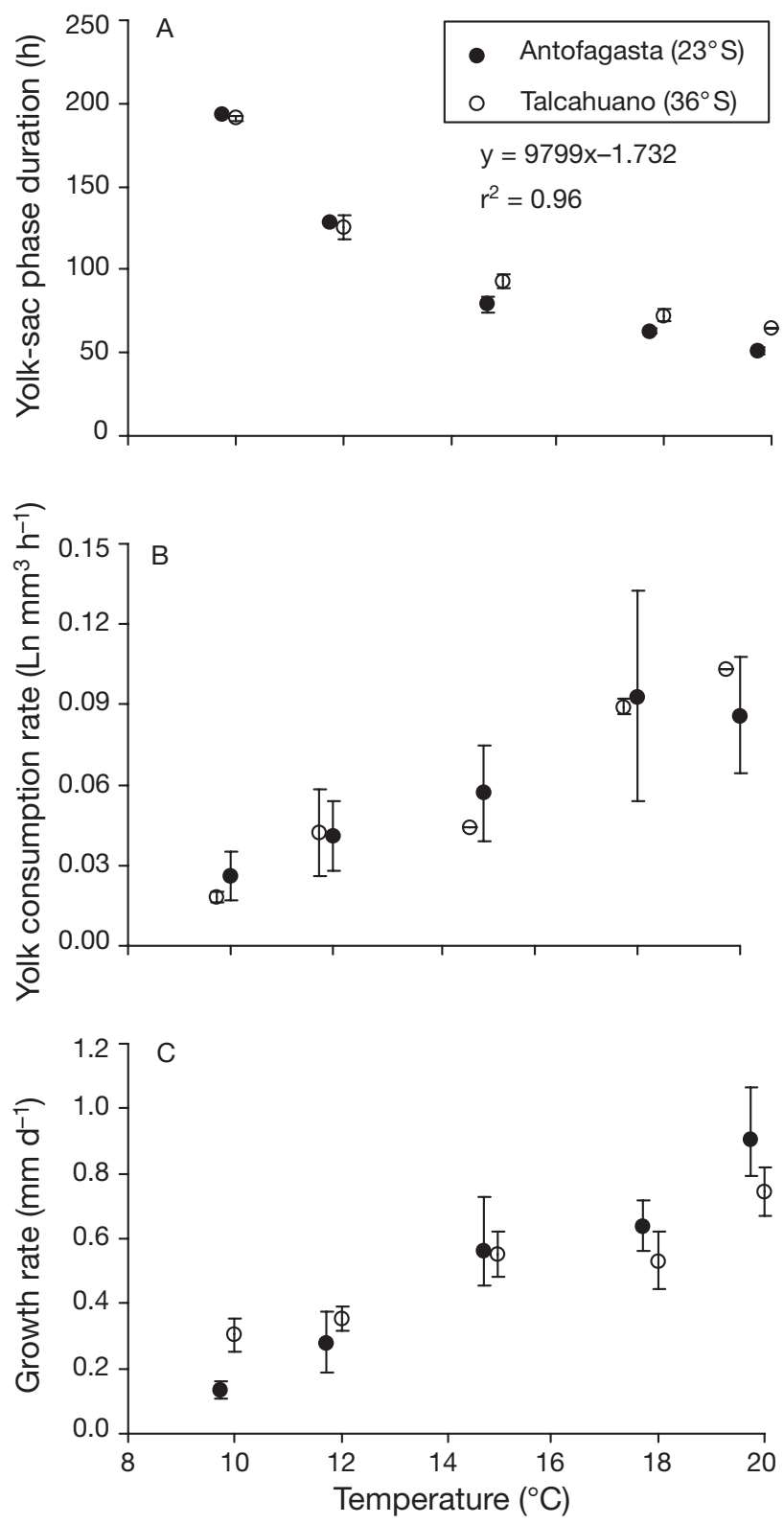

Fig. 3. Engraulis ringens. Effect of temperature on developmental rates of yolk-sac larvae. (A) Yolk-sac duration (mean \pm $\mathrm{SD})$ of 2 experimental trials carried out in Antofagasta and Talcahuano. (B) Yolk consumption rate (mean \pm SD) of 2 experimental trials carried out in Antofagasta and Talcahuano latitudes. (C) Growth rate (mean $\pm 95 \mathrm{CI}$ ) obtained by bootstrapping. Parameters utilized were obtained from a Gompertz model fitted to the Antofagasta and Talcahuano pooled experimental data

\section{DISCUSSION}

The purpose of this study was to evaluate the effect of temperature in characteristics of anchoveta Engraulis ringens early life stages and, secondly, to determine potential differences in these traits between populations of this species separated by $13^{\circ}$ of latitude.
Previous reports have shown that environmental conditions during the spawning season differ markedly between latitudes and also that differences existed in egg size spawned in both populations. Our results show a similar strong dependence on temperature of all rates measured in yolk-sac larvae from both populations, but also show that strong differences occurred in all larval size characters between populations.

\section{Temperature dependence}

Duration of yolk-sac phase, yolk consumption rate and larval growth rate until yolk exhaustion showed high thermic dependence in both populations. These traits showed no difference between populations when their larvae were reared in the temperature range between 12 and $20^{\circ} \mathrm{C}$, despite the differences in egg size. In other species, such as cod Gadus morhua and yellowtail flounder Pleuronectes ferrogineus, temperature also proved to have a greater influence than egg size on egg development rates and the duration of yolk-sac larvae (Pepin et al. 1996, Benoit \& Pepin 1999). As a consequence of the temperature dependence of biochemical reactions that drive metabolism, Pepin et al. (1996) proposed temperature as the dominant factor governing early development in cod. The overall results from our observations, therefore, suggest that: (1) temperature is the main factor driving these rate variations in both populations, except at the lowest temperatures; (2) there are no differences between areas in yolk-sac larval growth rates over most of the temperature range naturally experienced by these populations; and (3) some local adaptations might be occur, as evidenced by the higher growth rates at $10^{\circ} \mathrm{C}$ in the higher latitude population (Talcahuano), which is normally exposed to colder waters.

Larval length at hatch and initial yolk volume were modified by the rearing temperature to some extent. For instance, at the highest temperatures the length at hatch was smaller, as observed in other species. The size reduction has been explained as an effect of the temperature on the relative timing of phases of growth and differentiation (Blaxter 1992). In gadids, a dome-shaped type of response has been observed, with smaller sizes achieved at lower and higher temperatures (Chambers 1997). This dome pattern did not occur in the anchoveta. Similarly, in other clupeiformes species (e.g. Clupea harengus) the length at hatch and larval length at yolk absorption have also been reported not to vary over a wide range of temperatures $\left(3.5^{\circ} \mathrm{C}\right.$ at $17^{\circ} \mathrm{C}$, Overnell 1997). Whether there is a relationship between larval forms (elongated in clupeiforms vs. deeper in gadids) and the type of response to temperature (dome-shaped or other), should be dealt with in future studies. 
Table 4. Engraulis ringens. Parameters of Gompertz and linear models fit to growth of E. ringens yolk-sac larvae. $\mathrm{r}^{2}=$ determination coefficient; $L_{\mathrm{o}}=$ length at hatch; $G=$ dimensionless parameter; $g=$ instantaneous growth rate at age $t_{\mathrm{o} i} B=$ growth rate (slope $\mathrm{mm}^{-1}$ ); AIC: Akaike information criterion; N: number

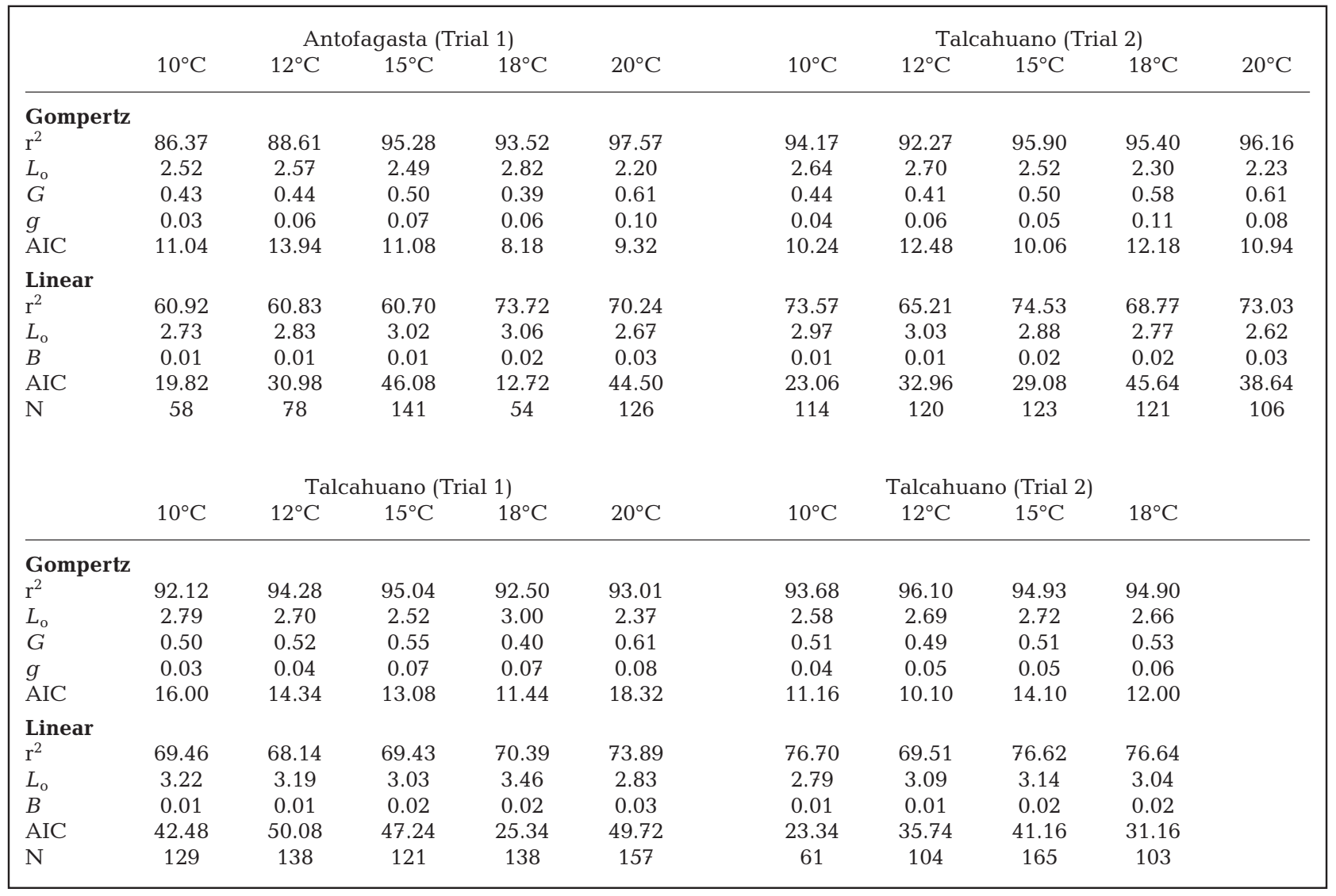

\section{Inter-population differences in egg-size-derived traits}

Larval length at hatch, initial yolk volume and larval length at yolk absorption were larger in individuals originated from Talcahuano eggs than in those hatched from Antofagasta (smaller eggs) (Fig. 4). In our study these larval traits varied among populations and were consistent with the initial differences in egg size spawned in both areas; thus, they could be the result of a maternal effect on the egg volume. The relation between egg size and morphological larval characteristics has been broadly discussed, and a direct relationship between egg size and larval size at hatch has been documented in several species (i.e. Gadus morhua, Pepin et al. 1996; Clupea harengus, Solea solea, Panagiotaki \& Geffen 1992).

Maternal effects on early life-history traits probably depend largely on the environmental conditions (i.e temperature, feeding conditions) experienced by females when energy is being acquired and converted during oogenesis (Chambers et al. 1989). In species such as capelin Mallotus villosus the initial mean yolk
Table 5. Engraulis ringens. Size $\left(\mathrm{mm}^{3}\right)$ of eggs used in experiments from Antofagasta and Talcahuano during 2001

\begin{tabular}{|c|c|c|c|c|}
\hline & \multicolumn{2}{|c|}{ Antofagasta $\left(23^{\circ} \mathrm{S}\right)$} & \multicolumn{2}{|c|}{ Talcahuano $\left(36^{\circ} \mathrm{S}\right)$} \\
\hline & Trial 1 & Trial 2 & Trial 1 & Trial 2 \\
\hline Date & 4 Aug & 7 Aug & $5 \mathrm{Sep}$ & $12 \mathrm{Sep}$ \\
\hline Mean egg volume & 0.266 & 0.259 & 0.302 & 0.292 \\
\hline SD & 0.021 & 0.023 & 0.023 & 0.026 \\
\hline $\mathrm{n}$ & 180 & 325 & 254 & 66 \\
\hline
\end{tabular}

volume of the eggs has been directly related to the condition and lipid indices of the female (Chambers et al. 1989). In other anchovies (Engraulis japonicus), fecundity and egg diameter have been related to environmental temperature. In the latter species, an increase in $3^{\circ} \mathrm{C}$ produced a decrease in $5.5 \%$ of the egg diameter; therefore, temperature probably modified the proportion of energy destined for reproduction (Funamoto \& Aoki 2002). Temperatures prior and during the anchoveta reproductive season differ by at least $3^{\circ} \mathrm{C}$ between the southern Talcahuano and Antofagasta spawning areas. Thus, differences in egg size between 

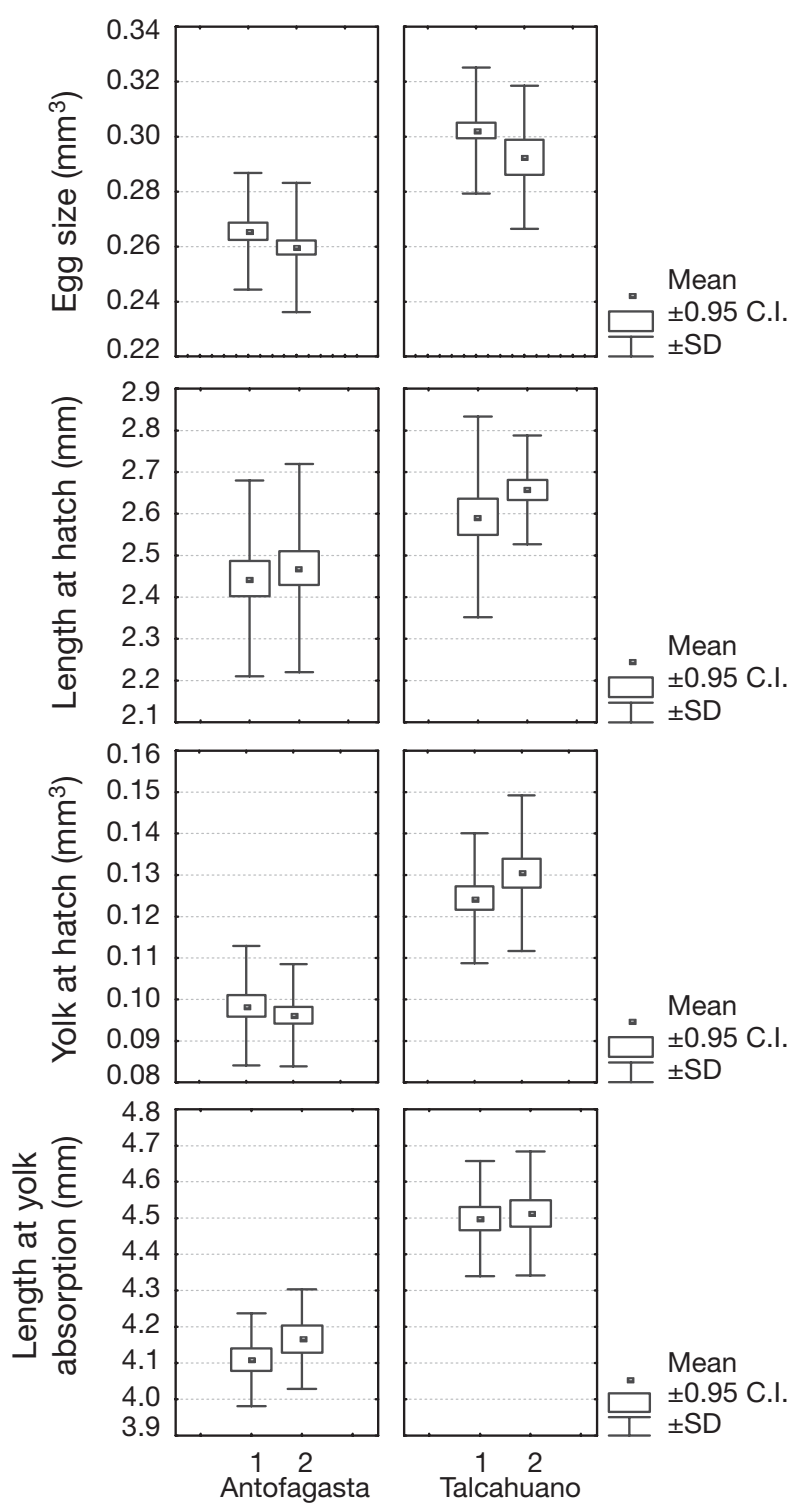

Fig. 4. Engraulis ringens. Box plots of each experimental trial (1 and 2) for egg size and larval characteristics from Antofagasta and Talcahuano during the winter spawning season 2000

populations of anchoveta are probably the result of dissimilar environmental conditions experienced by the adults during oogenesis in both geographical areas.

\section{Implications for populations located in different environments}

The results of this study are relevant when extrapolated from the environmental conditions prevailing in each nursery area (i.e. $15^{\circ} \mathrm{C}$ Antofagasta and 11 to $12^{\circ} \mathrm{C}$ Talcahuano). Anchoveta larvae hatching at Talcahuano are larger and have a larger amount of yolk than larvae from Antofagasta. The rate of yolk utilization for transformation towards new larval tissue is slower, and the duration of the yolk-sac phase is longer in larvae from Talcahuano $(5 \mathrm{~d}$ compared with $3 \mathrm{~d}$ for larvae from Antofagasta). The larval length differences observed at the end of the yolk-sac phase correspond to the length differences at hatching, and both factors (larval length at hatch and larval length at yolk absorption) are maternal effects originally expressed in the eggs (i.e. egg volume in the southern population is $>15 \%$ that in the northern population; Table 5). The higher growth rates of the Antofagasta yolk-sac larvae and the resulting sizes at yolk absorption do not compensate for the initial differences in sizes at hatch (i.e. length at yolk absorption Antofagasta: $4.15 \mathrm{~mm}$ at $15^{\circ} \mathrm{C}$; Talcahuano: $4.42 \mathrm{~mm}$ at $12^{\circ} \mathrm{C}_{i}$ see Table 2 ). As a final result, at the end of the yolk-sac stage, larvae from Talcahuano begin their exogenous feeding at a larger size. This increased length at yolk-sac absorption means larger mouth sizes, which might result in enhanced capture abilities, increased resistance to starvation (Shirota 1970, Hunter 1981, Fukuhara 1990) and enhanced chances of survival under adverse environmental conditions, such as increased turbulence, lower temperature and lower food availability during winter. These are the normal conditions experienced by the young anchoveta larvae in the southern spawning area (Castro et al. 2001). Therefore, the maternal effect of larger egg size and, moreover, of increased yolk volume in recently hatched larvae in the southern individuals seem advantageous results of the reproductive process during oogenesis to the comparatively more adverse austral environmental conditions faced by the young larvae.

Acknowledgements. The authors thank Drs. R. Escribano and E. Tarifeño for early reviews of the manuscript. P. Hidalgo, J. Rodriguez, M. Carmona and J. Marileo helped during the rearing experiments. R. Wiff gave statistical assistance. Dr. J. L. Blanco provided the data for Fig. 1. Funding for this investigation was provided by FONDECYT 1990470 to L.R.C., E. Tarifeño and R. Escribano and also by FONDECYT 1030819 to L.R.C. and Claramunt. The first author (A.L.-R) was partially funded by the Graduate School of the Universidad de Concepcion.

\section{LITERATURE CITED}

Benoît H, Pepin P (1999) Interaction of rearing temperature and maternal influence on egg development rates and larval size at hatch in yellowtail flounder (Pleuronectes ferrugineus). Can J Fish Aquat Sci 56:785-794

Blaxter JHS (1992) The effect of temperature on larval fishes. Neth J Zool 42 (2/3):336-357

Brown J, Ehtisham A, Conover D (1998) Variation in larval growth rate among striped bass stocks from different latitudes. Trans Am Fish Soc 127:598-610 
Castro L, Hernández E (2000) Early life survival of the anchoveta Engraulis ringens off central Chile during the 1995 and 1996 winter spawning seasons. Trans Am Fish Soc 129:1107-1117

Castro L, Llanos A, Blanco J, Tarifeño E, Escribano R, Landaeta M (2001) Influence of latitudinal variations in spawning habitat characteristics on the early life history traits of the anchoveta, Engraulis ringens, off northern and central Chile. GLOBEC Rep 16:42-45

Chambers RC (1997) Environmental influences on egg and propagule sizes in marine fishes. In: Chambers RC, Trippel EA (eds) Early life history and recruitment in fish populations. Chapman \& Hall, London, p 63-102

Chambers RC, Leggett W, Brown J (1989) Egg size, female effects, and correlations between early life history traits of capelin, Mallotus villosus: an appraisal at the individual level. Fish Bull US 87:515-523

Conover D (1990) The relation between capacity for growth and length of growing season: evidence for and implications of countergradient variation. Trans Am Fish Soc 119: $416-430$

Cubillos L, Canales M, Bucarey D, Rojas A, Alarcón R (1999) Época reproductiva y talla media de primera madurez sexual de Strangomera bentincki y Engraulis ringens en el período 1993-1997, zona centro-sur de Chile. Investig Mar 27:73-85

Fisher W (1958) Huevos, crías y primeras prelarvas de la anchoveta Engraulis ringens Jenyns. Rev Biol Mar 8 $(1 / 2 / 3): 111-124$

Fukuhara O (1990) Effects of temperature on yolk utilization initial growth, and behavior of unfed marine fish larvae. Mar Biol 106:169-174

Funamoto T, Aoki I (2002) Reproductive ecology of Japanese anchovy off Pacific coast of eastern Honsh, Japan. J Fish Biol 60:154-169

Gaughan D, Fletcher W, White K (2001) Growth rate of larval Sardinops sagax from ecosystems with different levels of productivity. Mar Biol 139:831-837

Hernández E, Castro L (2000) Larval growth of the anchoveta Engraulis ringens during the winter spawning season off central Chile. Fish Bull US 98:704-710

Houde E (1989) Comparative growth, mortality, and energetics of marine fish larvae: temperature and implied latitudinal effects. Fish Bull US 87:471-495

Hunter JR (1981) Feeding ecology and predation of marine fish larvae. In: Lasker R (ed) Marine fish larvae. Washington Sea Grant, Seattle, WA, p 33-77

Kamler E (1992) Early life history of fish: an energetics approach. Chapman Nadal, New York

Kamler E, Szlaminska M, Kuczynsky M, Hamackova J, Kouril J, Dabrowski R (1994) Temperature-induced

Editorial responsibility: Kenneth Sherman (Contributing Editor), Narragansett, Rhode Island, USA changes of early development and yolk utilization in the African catfish Clarias gariepinus. J Fish Biol 44(2): $311-326$

Koumoundouros G, Divanach P, Anezaki L (2001) Temperature-induced ontogenetic plasticity in sea bass (Dicentrarchus labrax). Mar Biol 139:817-830

Lasker R (1964) An experimental study of the effect of temperature on the incubation time, and growth of Pacific sardine embryos and larvae. Copeia 2:399-405

Llanos-Rivera A, Castro L (2004) Latitudinal and seasonal egg size variation of the anchoveta Engraulis ringens, off the Chilean coast. Fish Bull US 102:207-212

Lo $\mathrm{N}$ (1985) A model for temperature-dependent northern anchovy egg development and an automated procedure for the assigment of age to staged eggs. In: Lasker R (ed) A egg production method for estimating spawning biomass of pelagic fish: application to the northern anchovy, Engraulis mordax. NOAA Tech Rep NMFS 36:43-50

Manly BFJ (1997) Randomization, bootstrap and Monte Carlo methods in biology. Chapman \& Hall, London

Miller T, Crowder L, Rice J, Marschall E (1988) Larval size and recruitment mechanisms in fishes: toward a conceptual framework. Can J Fish Aquat Sci 45:1657-1670

Otterlei E, Nyhammer G, Folkvord A, Stefansson S (1999) Temperature- and size-dependent growth of larval and early juvenile Atlantic cod (Gadus morhua): a comparative study of Norwegian coastal cod and northeast Arctic cod. Can J Fish Aquat Sci 56:2099-2111

Overnell J (1997) Temperature and efficiency of development during endogenous feeding in herring embryos and yolksac larvae. J Fish Biol 50:358-365

Panagiotaki P, Geffen AJ (1992) Parental effects on size variation in fish larvae. J Fish Biol 41(B):37-42

Pepin P, Orr DC, Anderson J (1996) Time to hatch and larval size in relation to temperature and egg size in Atlantic cod (Gadus morhua). Can J Fish Aquat Sci 54(1):2-10

Quinn T, Deriso R (1999) Quantitative fish dynamics. Oxford University Press, Oxford

Serra J, Rojas O, Aguayo M, Hinostroza F, Cañon J (1979) Anchoveta (Engraulis ringens) In: Estado actual de las principales pesquerías nacionales. Bases para un desarrollo pesquero. Corporación de Fomento de la Producción. Instituto de Fomento Pesquero, Santiago

Shirota A (1970) Studies on the mouth size of fish in the larval and fry stages. Bull Jpn Soc Sci Fish 36:353-368

Van der Meeren T, Jorstad K (2001) Growth and survival of Arcto-Norwegian and Norwegian coastal cod larvae (Gadus morhua) reared together in mesocosms under different light regimes. Aquaculture 32(7):549-563

Zar J (1984) Biostatistical analysis. Prentice Hall, Englewood Cliffs, NJ

Submitted: September 21, 2004; Accepted: September 26, 2005 Proofs received from author(s): March 17, 2006 